



\section{Klimaendringer i Arktis - Studie 5}

Forstudie til kartlegging i kunnskaps- og koordineringsbehov av nordisk forskningssamarbeid

Grete K. Hovelsrud, Jonas Vevatne og Synne Putri Solstad

TemaNord 2007:511 


\section{Klimaendringer i Arktis - Studie 5}

Forstudie til kartlegging i kunnskaps- og koordineringsbehov av nordisk forskningssamarbeid

\section{TemaNord 2007:511}

(c) Nordisk Ministerråd, København 2006

ISBN 978-92-893-1455-8

Trykk: Ekspressen Tryk \& Kopicenter

Omslag: Kjell Olsson

Opplag: 300

Trykt på miljøvennlig papir som oppfyller kravene i den nordiske miljøsvanemerkeordning. Publikasjonen kan bestilles på www.norden.org/order. Flere publikasjoner på www.norden.org/publikationer

Printed in Denmark

\section{Nordisk Ministerråd}

Store Strandstræde 18

DK-1255 København K

Telefon (+45) 33960200

Fax (+45) 33960202

\section{Nordisk Råd}

Store Strandstræde 18

DK-1255 København K

Telefon (+45) 33960400

Fax (+45) 33111870

www.norden.org

\section{Det nordiske samarbeid}

Det nordiske samarbeid er en av verdens mest omfattende regionale samarbeidsformer. Samarbeidet omfatter Danmark, Finland, Island, Norge og Sverige, samt de selvstyrende områdene Færøyene, Grønland og Åland.

Det nordiske samarbeid er både politisk, økonomisk og kulturelt forankret, og er en viktig medspiller i det europeiske og internasjonale samarbeid. Det nordiske fellesskap arbeider for et sterkt Norden i et sterkt Europa.

Det nordiske samarbeid ønsker å styrke nordiske og regionale interesser og verdier i en global omverden. Felles verdier landene imellom er med til å styrke Nordens posisjon som en av verdens mest innovative og konkurransekraftige regioner. 


\section{Forord}

Denne forstudien om arktisk klimaforskning har sin bakgrunn i rekommandasjon 18/2005 fra Nordisk Råd. Nordisk Ministerråd for utdanning og forskning, MR-U, besluttet med bakgrunn i rekommandasjonen at det gjennomføres en analyse av kunnskaps-, koordineringsbehov og forutsetninger for en fortsatt og langsiktig nordisk forskningssatsning på klimaog miljøforandringer i Arktis, samt disse forandringenes konsekvenser for befolkningene i området. Som en del av denne analysen gjennomføres en avgrenset forstudie for å undersøke hvilke forutsetninger i form av innretning, utforming $\mathrm{mm}$. som analysen skal ha og deretter selve hovedanalysen.

Jeg er glad for at det nå gjøres en samlet nordisk innsats for at konsekvensene av klimaendringene blir kartlagt - med utgangspunkt i denne rekommandasjonen fra Nordisk Råd.

Store deler av den nordiske befolkningen lever i sub-arktiske og arktiske regioner, og Norden forvalter betydelige land- og havområder her. Nordiske land har en felles historie og en geografisk nærhet til, samtidig som nordiske land har mange fellestrekk, holdninger og prioriteringer og kjenner hverandre godt fra før, noe som gjør det gunstig å samarbeide. Vi står overfor mange like utfordringer.

Miljøsituasjonen i Arktisk er et hovedtema for det norske formannskapet i Nordisk Ministerråd i 2006. Problemstillingene i nordområdene er mange og sammensatte. Den økte politiske oppmerksomheten om nordområdene er knyttet både til ressursutnyttelse og samfunnsmessige forhold. Dette krever tverrfaglig forskning og et engasjement på tvers av alle de nordiske land. 
6

Kunnskaps- og koordineringsbehov av nordisk forskningssamarbeid

Norden bør stå sentralt i det internasjonale forskningssamarbeidet $\mathrm{i}$ nordområdene. Det er behov for å styrke et samordnet nordisk samarbeid om den arktiske forskningen. Ikke minst er det behov for et samarbeid for å øke kunnskapen om klimaendringene i Arktis.

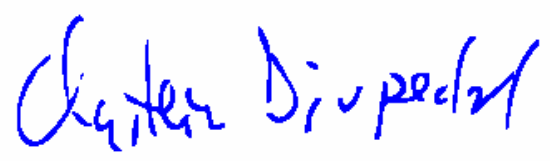

Øystein Djupedal

Kunnskapsminister 


\section{Innholdsfortegnelse}

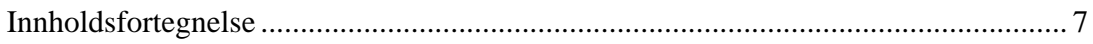

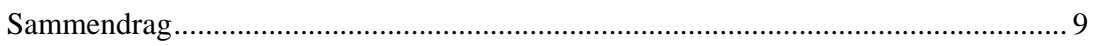

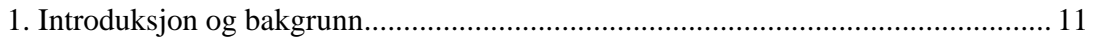

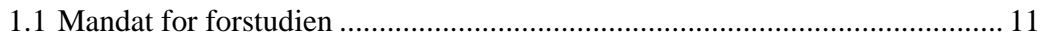

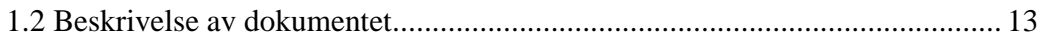

2. Bakgrunn: Et utvalg av sentrale anbefalinger for arktisk klimaforskning .............. 15

2.1 Nordisk strategi for klima og miljøgifter i Arktis.......................................... 15

2.2 Arctic Climate Impact Assessment (ACIA) ................................................. 17

2.3 Arctic Human Development Report - AHDR ............................................... 18

2.4 International Conference on Arctic Research Planning - ICARP II................ 19

2.5 NorACIA - den norske oppfølgingen av ACIA ............................................ 20

2.6 Nordisk forskningsstrategi på klimaendringer i Arktis.................................. 21

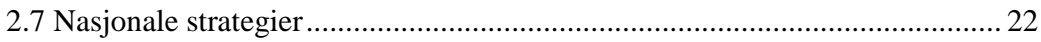

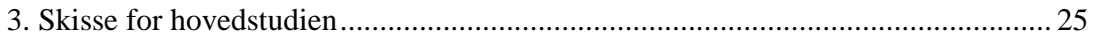

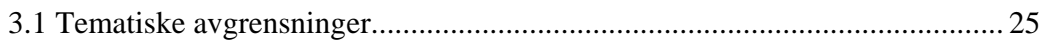

3.1.1 Fokusering på klimaendringer og deres virkninger på samfunn, mennesker og institusjoner i Arktis. ............................................ 25

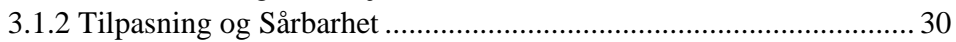

3.1.3 Ekstreme Hendelser ................................................................ 30

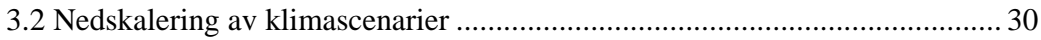

3.2.1 Klimaendringenes effekt på natur og miljø.................................... 31

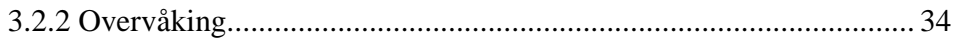

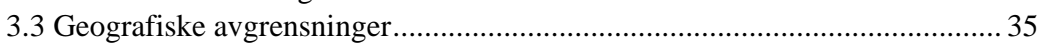

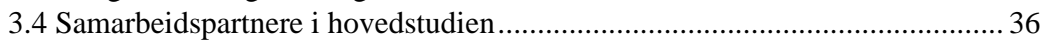

3.5 Budsjett, organisering og leveranser ............................................................ 37

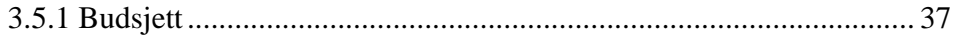

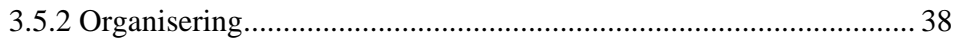

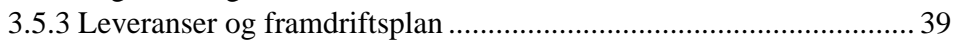

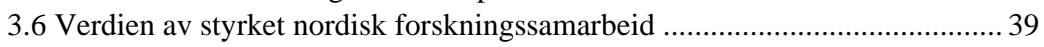




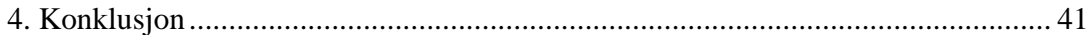

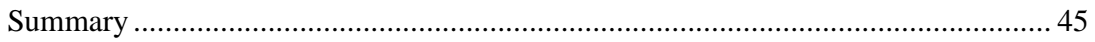

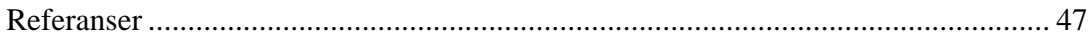

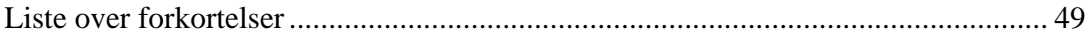




\section{Sammendrag}

Bakgrunnen for denne forstudien er de akselererende klimaendringene som særlig foregår i arktiske områder, og som også har konsekvenser for de nordiske land. CICERO - Senter for klimaforskning har foretatt en gjennomgang av de ulike vitenskapelige problemstillingene som er relevante i forhold til studier av klima- og miljøendringer. Målet med forstudien er å designe en hovedstudie som analyserer kunnskaps- og koordineringsbehov innenfor nordisk klima- og miljøforskning samt kartlegge forutsetningene for en langsiktig nordisk forskningssatsning på klima- og miljøforandringer, og konsekvenser disse har for arktiske samfunn. De samfunnsmessige aspektene ved klimaendringer er tillagt stor vekt fordi det er et stort behov for å forstå hvilke direkte og indirekte konsekvenser klimaendringer har på de ulike samfunn og befolkninger, og deres ressursgrunnlag og livsbetingelser.

Det er en rekke områder hvor et felles nordisk koordinerings- og forskningssamarbeid vil øke den samlede forståelsen og dermed øke verdiskapning for de nordiske land. Forstudien konkluderer med at en hovedstudie bør vurdere nærmere koordinering og kunnskapsbehov innen fire hovedområder:

- Samfunn: Sammenlignende studier og bredere forståelse av samfunnenes tilpasningsstrategier, kapasitet og sårbarhet. Herunder forståelse av sammenhengen mellom ulike påvirkningsfaktorer multiple stressors (klima, miljø og samfunn).

- Klimascenarier: Videre utvikling av regionale klimamodeller, og statistisk og empirisk nedskalering.

- Overvåking: Utvikling av plattformer for overvåking av miljø og klima. 
- Prosessforståelse: Øke forståelsen av hva som påvirker klimautviklingen i Nordområdene både terrestrisk og marint.

Hovedstudien må vurdere verdiskapning i forhold til om et koordineringsog forskningssamarbeid vil bidra til at de enkelte nordiske land blir bedre i stand til å takle konsekvensene av klimaendringer for samfunn og miljø, og om Norden som en enhet kan påvirke internasjonale prosesser og utvikling av strategier. Et slikt arbeid bør på et overordnet nivå ledes av forskningsrådene i de ulike land i nært samarbeid med vitenskapelige eksperter. 


\section{Introduksjon og bakgrunn}

\subsection{Mandat for forstudien}

Akselererende klimaendringer i Arktis, og forskning på årsaker og konsekvenser til disse, er dokumentert i flere sammenhenger særlig i Arctic Climate Impact Assessment (ACIA), Arctic Human Development Report (AHDR), Nordic Arctic Research Programme (NARP) og International Conference on Arctic Research Planning (ICARPII). (ACIA 2005, AHDR 2004, NARP 2005, ICARPII 2006). Geografisk nærhet gjør at urovekkende endringer i arktiske strøk, som også har store konsekvenser for mennesker som bor i disse områdene, ikke kan ignoreres av de nordiske land. I Norden fins det forskningsmiljøer som gir en god basis for å gjennomføre en analyse av behovene og forutsetningene for «videre og langsiktige forskningsinnsatser med fokus på klima - og miljøforandringer i Arktis». ${ }^{1}$

Nordisk Ministerråd for utdanning og forskning (MR-U) har besluttet med bakgrunn i en rekommendasjon fra Nordisk Råd, at

«...det genomförs analys av kunskaps-, koordineringsbehov och förutsättningar för en fortsatt och långsiktig nordisk forskningssatsning på klimat- och miljöförändringar i Arktis, samt dessa förändringars konsekvenser för befolkningarna i området. Som en del av denna analys genomförs en avgränsad förstudie i syfte att undersöka vilka förutsättningar i form av inriktning, utformning mm. som analysen skall ha och därefter själva huvudanalysen. Detta skall ske i samarbete och dialog med NordForsk, samt andra relevanta aktörer inom området.»

\footnotetext{
${ }^{1}$ Her inkluderer vi forskning i Norden og annen kunnskapsproduksjon fra arktiske områder, med relevans for samfunnsplanlegging i de nordiske landene.
} 
CICERO gis følgende mandat for gjennomføring av en forstudie:

CICERO skal, i samarbeid med NordForsk og eventuelt andre relevante partnere, designe en hovedstudie som analyserer kunnskaps- og koordineringsbehov innenfor nordisk klima- og miljøforsking, samt kartlegge forutsetninger for en langsiktig nordisk forskningssatsning på klima- og miljøforandringer, og konsekvenser disse har for befolkningen, i Arktis.

Forstudien skal:

- Ta utgangspunkt i relevante forskningsstrategier både på nasjonalt, nordisk og internasjonalt nivå

- Ta hensyn til anbefalingene i relevante dokumenter som Strategi for klima og miljøgifter i Arktis, ACIA og AHDR.

- Anbefale geografiske, tematiske og faglige avgrensinger

- Identifisere samarbeidspartnere i hovedstudien

- Foreslå budsjett, organisering, leveranser og framdriftsplan for hovedstudien innenfor en antatt samlet ramme på 800.000 DKK

Oppdraget og initiativet må også ses i lys av forskningsministrenes ønske om styrket forskningssamarbeid mellom de nordiske landene, jf. for eksempel de nordiske forskningsministres felles artikkel fra 2004: «Norden - En af de ledende regioner indenfor forskning og innovasjon». Når det gjelder klimaforskning, er det sannsynlig at de nordiske landene gjennom økt samarbeid og koordinering innenfor enkelte områder kan oppnå mer enn om de operer på egenhånd, og de vil kunne bidra med noe ekstra til det internasjonale forskningsmiljøet. Årsaken er at Norden har naturgitte forutsetninger og spesiell kompetanse på enkelte forskningsområder i tillegg til relativt gode forskningsbudsjetter. Gjennom samordning og mer felles effektiv utnyttelse av ressursene kan disse egenskapene trolig utnyttes bedre og samlet sett styrke de nordiske landenes klimaforskning. De nasjonale strategiene må ligge i bunn når en hovedstudie skal vurdere på hvilke områder et styrket nordisk samarbeide vil være mest hensiktsmessig og nyttig. Det vil videre være en viktig oppgave for hovedstudien å identifisere hvilke områder innen klimaforskningen i Arktis de nordiske landene kan oppnå mer sammen enn hver for seg. 
Oppdragsgiver er: Nordisk ministerråd (NMR) Avdelningen for utdanning, forskning og arbeidsliv (UFA).

Referansegruppe: Kate Runeberg (NMR), Gard Titlestad (NMR), Harry Zilliacus (NordForsk), Christopher Brodersen (Bioforsk) og Thomas Hansteen (NFR).

\subsection{Beskrivelse av dokumentet}

I denne forstudien tar vi utgangspunkt i klimaendringer i Norden, med tanke på hvilke vitenskapelige problemstillinger som er mest relevante for et nordisk samarbeid. Under klimaendringer i dette dokumentet ligger også miljøendringer som kommer som konsekvens av klimaendringer, og som har konsekvens for samfunn i Norden, og modellering av fremtidens klima. Det vil legges vekt på konsekvensene av klimaendringer på mennesker og samfunn. Dette henger igjen nøye sammen med påvirkningene av klimaendringer på miljø og naturressurser. Denne forstudien vil videre ta utgangspunkt $i$ at en hovedstudie bør kunne gi svar på:

1. hva slags kunnskapsbehov Norden har omkring konsekvensene av klimaendringene, så som samfunnsmessige tilpasningsbehov, miljøendringer, forurensing, overvåkingsbehov og forståelse av fremtidens klima i nordområdene,

2. hvordan og på hvilken måte et styrket nordisk forskningssamarbeid vil øke den samlede forståelsen, og

3. gi en forståelse av verdiskapningen et slikt koordinerings- og forskningssamarbeid vil føre til for de nordiske land, både enkeltvis og som en region.

Denne forstudien består av fire deler, en kort introduksjon og bakgrunn, et lite utvalg av relevante anbefalinger for nordisk/arktisk klimaforskning, en detaljert skisse av hovedstudien med anbefalinger under hvert tema og en kort analyse av verdien av styrket nordisk samarbeid, og en konklusjon hvor anbefalingen er samlet. 



\section{Bakgrunn: Et utvalg av sentrale anbefalinger for arktisk klimaforskning}

\subsection{Nordisk strategi for klima og miljøgifter i Arktis}

Kunnskap om klimaendringer i Arktis er beskrevet som strategisk viktig for Nordisk Ministerråd (NMR) og de nordiske landenes arbeid med å begrense utslippene av klimagasser. Derfor har de nordiske miljøvernministrene vedtatt en strategi som primært skal tjene som plattform i det videre miljøsamarbeidet innen Nordisk Ministerråd. ${ }^{2}$

Norden skal øke og formidle kunnskap om klimaendringer i Arktis, og konsekvensene regionalt og globalt, med sikte på å redusere utslipp av klimagasser i tråd med Klimakonvensjonens langsiktige mål. Grunnet sin geografiske plassering har Norden et spesielt ansvar for å formidle kunnskap om klimaendringer og konsekvenser av disse i Arktis. Strategien understreker at det er viktig å fokusere på «den arktiske dimensjon» og å tette kunnskapshull. Klima påvirker miljøgiftenes transport og effekter, og en global oppvarming vil også øke mengden miljøgifter og forurensning i Arktis.

Kunnskap om klimaendringer i Arktis bør utnyttes for å påvirke internasjonale fora til å begrense utslipp av klimagasser og i utformingen av EUs klimapolitikk. Videre må de nordiske landene sikre «den Arktiske dimensjonen» i forhandlinger under Klimakonvensjonen og gjøre den synlig i IPCCs fjerde hovedrapport, og også ivareta denne i andre diskusjonsarenaer. Formidlingstiltak som sprer oppmerksomhet rundt klimaendringer i Arktis må også prioriteres.

\footnotetext{
${ }^{2}$ Geografisk er strategien avgrenset til å gjelde problemstillinger som er spesielt relatert til de delene av Norden som ligger innenfor det arktiske området slik dette er definert av Arktisk Råds arbeidsgruppe Arctic Monitoring and Assessment Programme (AMAP) og i Arctic Climate Impact Assessment (ACIA) rapportene (ACIA, 2004; ACIA, 2005).
} 
Dagens tilpasningsstrategier er ikke gode nok blant annet på grunn av manglende regionale klimamodeller. Videre utvikling av regionale klimamodeller er derfor et område som også må prioriteres.

Rapporten peker på at det er nødvendig å ha et sterkt fokus på sårbarhet og tilpasning med en helhetlig tilnærming til klimautfordringen. Ved god spredning av nasjonale tilpasningsstrategier mellom de nordiske landene sikrer man en helhetlig strategi. Kunnskap om sårbarhet og tilpasning kan bli ivaretatt gjennom å styrke initiativ fra EU, EEA, Arktisk Råd og Barentsrådet.

Nordisk ministerråd vil vurdere sårbarhet i tradisjonelle kulturer i Norden, lokale arktiske næringer og naturmiljøet, og ekstremhendelser. Ministerrådet vil videre gjennomføre ekspertmøter for kunnskapsutveksling og utvikling med fokus på tilpasningsutfordringer i sårbare sektorer/områder.

Langsiktig overvåkning av prioriterte miljøindikatorer er et sentralt tema i strategien. De nordiske land er forpliktet til kunnskapsoppbygging, forskning og overvåkning av Klimakonvensjonen og Kyotoprotokollen. Det er strategisk viktig å tette kunnskapshull som bl.a. å forbedre regionale klimamodeller og utvikling av tilpasningsstrategier. En samordnet forskningsinnsats og langsiktig overvåkning ses som prioriterte områder.

Hovedmålsetningen for klima i strategien er at de nordiske land i fellesskap skal arbeide for å øke og spre kunnskap om klimaendringer i Arktis og deres konsekvenser regionalt og globalt, med sikte på å redusere de globale utslippene av klimagasser i tråd med Klimakonvensjonens langsiktige mål.

- Delmål Klima 1: Utnytte kunnskap om klimaendringer i Arktis for å påvirke internasjonale fora til å begrense utslipp av klimagasser i tråd med Klimakonvensjonens langsiktige mål.

- Delmål Klima 2: Utnytte kunnskap om klimaendringer i Arktis for å støtte opp om tilpasningsarbeidet i regionen.

- Delmål Klima 3: Støtte utvikling av kunnskap på særlig viktige områder samt langsiktig overvåkning av prioriterte miljøindikatorer.

I tillegg er det tredje delmålet under hovedmålet for miljøgifter også av svært stor relevans for hovedstudien:

- Delmål Miljøgifter 3: Sette søkelys på klimaendringers innvirkning på spredning og effekter av miljøgifter i Arktis. 


\subsection{Arctic Climate Impact Assessment (ACIA) ${ }^{3}$}

ACIA-rapporten, utarbeidet på bestilling fra Arktisk Råd og lagt frem ved Arktisk Råds Ministermøte i Reykjavik i 2004, foreslår tre hovedprioriteringer for videre forskningsinnsats i Arktis: regionale konsekvenser, sosioøkonomiske konsekvenser og sårbarhet. Alle disse områdene vil bidra til å øke forståelsen for effektene av klimaendringer på samfunn, miljø og ressurser men for å få dette til er det nødvendig å involvere et bredt spekter av vitenskapelige og andre eksperter og interessenter, særlig de arktiske urfolkssamfunnene, for å bidra til å fylle kunnskapshullene og skaffe relevant informasjon for beslutningstakere på alle lokale, nasjonale, regionale og internasjonale nivåer (ACIA 2004: 122-123).

Sub-regionale konsekvenser: I fremtidige vurderinger er det behov for å fokusere på mindre regioner, kanskje helt ned på lokalnivå, der en vurdering av klimaendringers konsekvenser har størst relevans og nytte for beboerne og deres aktivitet.

Sosioøkonomiske konsekvenser: Viktige økonomiske sektorer i Arktis inkluderer olje- og gass-utvinning, gruvedrift, transport, fiskeri, skogbruk og turisme. De fleste av disse sektorene vil påvirkes direkte eller indirekte av klimaendringer, men i de fleste tilfeller finnes det i dag bare kvalitativ informasjon om de økonomiske konsekvensene.

Vurdering av sårbarhet: Med sårbarhet forstås i hvilken grad et system er følsom overfor ugunstige påvirkninger forårsaket av flere samspilllende stressfaktorer (for eksempel klimaendringer, sosio- økonomiske endringer, ressursforvaltning). Vurdering av sårbarhet krever kunnskap om systemets tilpasningsevne og om konsekvensene av de ulike stressfaktorene og samspillet mellom dem.

For å takle disse tre høyprioriterte emnene må det foretas en rekke forbedringer med hensyn til langsiktig overvåking, prosesstudier, klimamodellering og analyser av samfunnskonsekvenser.

Langsiktig overvåking: Lange tidsserier for klima og klimarelaterte elementer finnes fra svært få steder i Arktis. Det er svært viktig å ha slike lange tidsserier samtidig som man oppgraderer og utvider overvåkings-

\footnotetext{
${ }^{3}$ Arctic Climate Impact Assessment (ACIA) er en utredning der de åtte arktiske landene Canada, Danmark, Finland, Island, Norge, Russland, Sverige og USA - har gjennomført en omfattende vurdering og analyse av hvilke konsekvenser klimaendringer vil kunne ha for miljø og samfunn i Arktis. Det fireårige prosjektet er gjennomført i regi av Arktisk Råd, og 250 forskere har deltatt.
} 
systemene for snø og is, avrenning fra de største elvene, havparametere og endringer i vegetasjonen, biologisk mangfold og økosystemprosesser.

Prosesstudier: Mange prosesser i Arktis må undersøkes mer inngående, både gjennom vitenskapelig forskning og gjennom mer detaljert og systematisk dokumentasjon av urfolkenes kunnskap. Blant de prioriterte oppgavene er innsamling og tolking av data om klima og det fysiske miljøet samt studier av hastighet og omfang av endringer for planter, dyr og økosystemfunksjoner. Slike undersøkelser innebærer ofte kobling av klimamodeller med modeller for økosystemprosesser og andre forhold i det arktiske systemet.

Modellering: Det er nødvendig å forbedre modellene for det arktiske klimaet og dets påvirkninger, blant annet inkludering av vannmiksing $\mathrm{i}$ havet og forbindelsen til havis, samspillet mellom permafrost, jordsmonn og vegetasjon, viktige tilbakekoblingsprosesser og ekstremhendelser. Modellforbedring og -verifisering er viktig innenfor vitenskapelige disipliner, og det er også nødvendig å knytte sammen og integrere modeller på tvers av vitenskapelige disipliner. Utvikling, verifisering og bruk av koblede regionale modeller med svært høy oppløsning for å forbedre fremskrivingen av regionale klimaendringer, vil også bidra til å fremskaffe mer nyttig informasjon til beslutningstakerne.

Analyse av samfunnskonsekvenser: Det å forbedre beregninger av klimaendringenes samfunnskonsekvenser vil til dels være avhengig av fremskritt i klimamodelleringene nevnt over, så vel som utvikling av forbedrede scenarier for befolkningsutvikling og for økonomisk utvikling i Arktis, utvikling og bruk av konsekvensscenarier, bedre kobling mellom forskernes kunnskap og urfolkenes kunnskap, og grundigere identifisering og analyse av potensielle tiltak for å dempe og tilpasse seg klimaendringer (ACIA 2005).

\subsection{Arctic Human Development Report - AHDR}

Fremleggelsen av en utvidet levekårsstudie (Arctic Human Development Report - AHDR) var et hovedprosjekt under det islandske formannskapet i Arktisk Råd. Målet for AHDR var å fremskaffe omfattende kunnskap om bærekraftig utvikling i Arktis innen fire hovedtemaer: policy relevante konklusjoner, suksesshistorier, kunnskapshull, regionale perspektiver 
på samfunnsutvikling og oppfølging og planlegging. AHDR inneholder uvurderlig data og informasjon i forhold til å øke forståelsen av klimaendringers virkninger på folk og samfunn fordi denne rapporten fremskaffer en omfattende kunnskapsbasis omkring leveforhold, styresett, helse og velvære, økonomiske, politiske og rettslige systemer i arktiske samfunn. Denne kunnskapen er en forutsetning for å kunne forstå kapasiteten til å kunne tilpasse seg klima og andre relaterte endringer og å utvikle gode tilpasningsstrategier til klimaendringene. I tillegg viser rapporten at det er behov for å inkludere tradisjonell kunnskap i arbeidet med tilpasning.

AHDR har identifisert områder hvor det er behov for økt kunnskap, og alle disse områdene har stor relevans for å forstå lokalsamfunns iboende evne og framtidige muligheter og kapasitet til å tilpasse seg klimaendringene.

Kultur og samfunn: Øke forståelsen for effektene av de kumulative endringene på kulturell og sosial velferd i Arktis.

Demografi: Innsamling av mer og bedre informasjon om befolkingen i Arktis ved å bruke vanlige dataprotokoller.

Nybyggere: Fokus på erfaringene til de nyankomne innflytterne i Arktis og dere samspill med regionens urbefolkning.

Industri: Forbedre forståelsen av hvilke roller moderne industrielle aktiviteter spiller i bestrebelsen for en bærekraftig utvikling på det regionale nivå.

Styresett: Økt innsats for å sammenlikne og kontrastere nye institusjoner i Arktis og overføre relevant lærdom ikke bare til Arktis, men også til andre deler av verden som er karakterisert av overflod av naturressurser, spredt bebyggelse og kulturelt mangfold (AHDR 2004).

\subsection{International Conference on Arctic Research Planning - ICARP II}

Den andre internasjonale ICARP konferansen ble holdt i København i november 2005 dreide seg om planlegging av arktisk forskning (ICARP II) under International Arctic Science Committee (IASC). ICARP II hadde som formål å definere og prioritere forskningstema i Arktis for de neste ti år. I alt deltok 450 forskere fra forskjellige land som drøftet alle relevante forskningsområder. ICARP II arbeider med følgende 11 tema: 
1. Bærekraftig utvikling og arktiske økonomier

2. Urbefolkninger og endringer i Arktis

3. Arktiske kystprosesser

4. Det dype sentralbassenget i Polhavet

5. Polhavets marginer

6. Arktiske kontinentalsokkelhav

7. Terrestre cryosfære og hydrologiske systemer

8. Terrestre biosfære og biodiversitet

9. Modellere og forutsi arktisk klima og økosystemer

10. Robusthet, sårbarhet og raske endringer

11. Forskning i publikums interesse

I ICARP II-rapporten, som er ventet i årsskifte 2006-2007, diskuteres de internasjonale anbefalingene for arktisk forskning de neste ti år i detalj. ICARP II vil utvilsomt være en viktig premissgiver for hovedstudien. Det anbefales at hovedstudien ikke påbegynnes før rapporten fra ICARP II foreligger.

\subsection{NorACIA - den norske oppfølgingen av ACIA}

NorACIA er den norske oppfølgingen av Arktisk Råd-prosjektet ACIA. NorACIA har en helhetlig tilnærming til klimaendringer som også inkluderer sosioøkonomiske og økologiske konsekvenser og understreker at klimaendringer ikke kan betraktes som isolert fra andre faktorer. NorACIA ser derfor en grunn til å følge utviklingen nøye og å sørge for til enhver tid å ha et godt og oppdatert kunnskapsgrunnlag tilgjengelig som dekker både naturvitenskaplige forhold og effektene på økosystemer og forskjellige samfunnssektorer. NorACIA har lagt vekt på følgende temaer:

1) Klimascenarier

2) Fysiske og biogeokjemiske prosesser

3) Effekter på økosystemer og biologisk mangfold

4) Virkninger på folk og samfunn

5) Tilpasningstiltak og avbøtende tiltak 
Relevant delmål: NorACIA skal gi en helhetlig og oppdatert regional analyse og vurdering av klimaendringer, konsekvenser og tilpasningstiltak i norsk del av Arktis basert på:

- $\quad$ nedskalerte regionale klimamodeller og oppdaterte scenarier for å vurdere sannsynlig klimautvikling for området

- $\quad$ kunnskap om de fysiske og biogeokjemiske prosessene som påvirker klimautviklingen i Arktis

- kunnskap om effekter på de mest sårbare samfunnssektorer og økologiske systemer

- utvikling av nødvendige tilpasningstiltak og institusjonelle grep, samt vurdere avbøtende tiltak som kan gjennomføres innenfor norsk del av Arktis

\subsection{Nordisk forskningsstrategi på klimaendringer i Arktis}

I de nordiske landene fins en hel rekke prosjekter og programmer som er rettet mot miljø- og klimaendringer i Arktis. ${ }^{4}$ Disse prosjektene er som oftest knyttet opp mot internasjonale samarbeidspartnere og få programmer har en uttalt nordisk forankring. Samarbeidende institusjoner jobber i størst grad med forskningsmiljøer de anser som faglig relevante fremfor at samarbeidet deres er grunnet i nasjonal tilhørighet. En hovedstudie bør vurdere fordelene og ulempene ved et nordisk forskningssamarbeid og en eventuell nordisk forskningsstrategi, for å fremme synkronisering og hindre fragmentering av forskningen som gjøres. Det nordiske samarbeidet har de senere årene vært gjennom betydelige omstruktureringer. Fokus har endret seg fra samarbeid om det særnordiske til samarbeid for å utvikle Norden til en sterk forskningsregion internasjonalt. Prioriterte områder, infrastruktur, finansiering og politiske anbefalinger er alle temaer landene må forholde seg til når det gjelder videre forskning på klimaendringer i Arktis og konsekvenser dette har for samfunn og miljø. Det

\footnotetext{
${ }^{4} \mathrm{NCoE}$-Nordic Centre of Excellence of Global Change, Biosphere-aerosol-cloud-climate interactions (BACCI), The dynamics of ecological systems under the influence of climatic variation (EcoClim), Nordic centre for studies of ecosystem carbon exchange and its interactions with the climate system (NECC) og nordiske samarbeidsnemnder innenfor fiskeri, land- og skogbruk, energi og næringsmidler er noen eksisterende program med nordisk forankring.
} 
synes å være en bred enighet om at en felles nordisk forskningsinnstas derfor er nødvendig (NordForsk). ${ }^{5}$

I Vitboken NORIA (Nordic Research and Innovation Area) «Vitbok om nordisk forskning og innovasjon», anbefales sterkt økt felles nordisk innsats. Det bør kartlegges hvor store investeringer som trengs for å skape vilkårene og infrastruktur som muliggjør nordisk forskning på toppnivå. Slik det er i dag melder NORIA at de nordiske land satser veldig lite felles på forskning og utvikling (FoU). Den samlede forskningsinnsats gir altfor lite midler i forhold til behovet for nordisk fellesinnsats på forskning og innovasjon. Eksisterende forskning på Arktis er gjerne flerfaglig og ikke nødvendigvis rettet mot klimaendring (Dr Strand Thule Inst. Personlig kommentar). Multilaterale finansieringsstrategier bør bli ytterligere oppmuntret i Norden, og potensialet her er stort. Forskning i Arktis krever store budsjetter, og samarbeid om finansiering er derfor helt nødvendig.

\subsection{Nasjonale strategier}

I hele Norden blir det satset på å øke det nordiske forskningssamarbeidet. Sverige har en uttalt målsetting om å styrke de områder der Norden kan hevde seg internasjonalt, eller på de vitenskapelige felter der de nordiske land har spesielle forutsetninger og interesser. For Finland er det spesielt viktig å ekspandere forskningssamarbeidet til Baltikum, arktisk forskning og et tettere samarbeid med Russland. Dansk forskningspolitikk betrakter Norden i størst mulig grad som et enhetlig utdannelses- og forskningsområde og dette medfører et sterkt fokus på nordisk forskningssamarbeid. Det er lagt vekt på at det skal være enkelt å utveksle ideer og bevege seg mellom de ulike forskningsmiljøer i Norden. Den nordiske dimensjonen

\footnotetext{
${ }^{5}$ NordForsk er et organisatorisk rammeverk som skal fremme nordisk forskningssamarbeid. I NordForsk 2006-2009 er det lagt vekt på mer forskningssamarbeid mellom nordiske land av flere grunner: Økt synlighet av den nordiske dynamiske regionen, øke vitenskapelig kvalitet, større kritisk masse og en bredere fellesplattform. Dette kaller NordForsk Nordic Strength. Videre bidrar følgende momenter til at det er naturlig å vurdere nærmere forutsetningene for et nordisk forskningssamarbeid på Arktis: Store deler av den nordiske befolkningen lever i subarktiske og arktiske regioner og Norden forvalter betydelig land- og havområder her. Nordiske land har en felles historie og en geografisk nærhet til Arktis som bidrar til en spesiell forpliktelse, samtidig som nordiske land har mange fellestrekk, holdninger og prioriteringer og kjenner hverandre godt fra før, noe som gjør det gunstig å samarbeide. De står også overfor mange like utfordringer, blant annet har den sikkerhetspolitiske dimensjonen økt betydelig de siste årene, og det eksisterer allerede gode samarbeidsformer med blant annet en høy FoU-satsing.
} 
skal forsterkes, og her får NordForsk en sentral rolle å spille som koordineringspunkt. Ifølge den norske nasjonale handlingsplan for klimaforskning, som ble lagt fram i august, er det særlige kunnskapsbehov i forhold til Arktis og Barentshavet (Norges Forskningsråd 2006). Planen påpeker at det er for lite engasjement fra flere departement når det gjelder finansiering og formidling av klimaforskning i Arktis og forståelsen av klimaog miljøforandringene der. Videre avdekker planen en for stor fragmentering innen klimaforskningen som kan skyldes relativt uavhengige styringssignaler fra departementene til Norges Forskningsråd. Norske myndigheter er svært opptatt av at det norske vitenskapelige arbeidet blir integrert i et større internasjonalt arbeid og det tas sikte på blant annet å delta aktivt i planleggingen av EUs 7.rammeprogram. I ERA-nett, European Research Area, er det nedfelt en nordisk undergruppe i det 6. rammeprogram, og dette vil få enda sterkere fokus i 7.rammeprogram. Målet er å øke utveksling og å få i gang fellesutlysninger og måter å gjøre dette på.

Også for Island er det satset mye på å utvikle det nordiske samarbeidet gjennom ERA, og dette vil bli videreført i de neste årene. En økt satsing på EUs Rammeverksprogram på Forskning og Teknologisk utvikling har vært en stor suksess og oppmuntret til ytterligere nordisk samarbeid. I denne forbindelsen kan det være verdt å nevne at Island de siste årene har formalisert og etablert et godt forskningssamarbeid også med USA. 



\section{Skisse for hovedstudien}

The current and projected changes in climate are expected to have serious global consequences, but with significant differences at national, regional and local levels (McCarthy m.fl. 2001).

Arktis gjennomgår raske endringer i miljøtilstanden, og i mange aspekt av de nordlige økonomiske og samfunnsmessige forhold. The Arctic Climate Impact Assessment (ACIA) forespeiler unike klimaendringer i Arktis, og forandringer er allerede blitt dokumentert gjennom instrumentelle data og lokale observasjoner gjort blant annet av urbefolkninger (McBean m.fl. 2005; Huntington og Fox 2005). The Arctic Human Development Report (AHDR) dokumenterer at befolkningen i Arktis er utsatt for endrede miljøforhold og allerede må tilpasse seg (AHDR 2004).

\subsection{Tematiske avgrensninger}

Det er mange tema som kan være aktuelle for nordisk samarbeid og det bør være en viktig oppgave for hovedstudien å foreta den endelige tematiske avgrensningen. I denne forstudien listes aktuelle tema som hovedstudien bør arbeide videre med, uten at det er fortatt noen prioritering mellom disse.

\subsubsection{Fokusering på klimaendringer og deres virkninger på samfunn, mennesker og institusjoner i Arktis.}

Klimaendringene i Arktis forventes å få store konsekvenser for miljø og samfunn. Klimaendringer er globale, tilpasning til disse endringene skjer lokalt, og tilpasningsstrategier utvikles både lokalt, regionalt og nasjonalt. Dette betyr at effektene av klimaendringer på samfunn hele tiden må vurderes på ulike samfunnsnivå samtidig. 
Lokalsamfunnenes kultur, økonomi og levemåte tilpasset det arktiske miljøet vil stå overfor alvorlige utfordringer som følge av klimaendringer. Urfolkene og andre lokalbefolkninger har på en unik måte utviklet innsikt, perspektiver og kunnskaper på Arktis som er spesielt verdifulle for videre forskning og forståelse av arktiske klimaendringer.

Med økt temperatur vil det åpne seg flere muligheter for landbruk i de nordlige regionene. Reduksjon i både utbredelse og tykkelse av havisen vil sannsynligvis øke tilgangen til store reservoarer av olje og gass i Barentshavet. Slike følger av klimaendringer kan føre til store endringer i økonomi, bosetting og sosial struktur for samfunnene i disse regionene. I noen tilfeller kan i verste fall de ovennevnte endringene true livsgrunnlaget til enkelte folkegrupper som Inuitter og reindriftsutøvere. Det er ikke bare næringsgrunnlaget som blir truet av klimaendringer, men også deres basis for kulturell og sosial identitet. De arktiske folkegruppenes tradisjonelle nærhet til dyr og miljø er i dag langt på vei like viktig for kulturenes overlevelse som mulighetene til å skaffe mat ved fangst og fiske. Forskere understreker hvor viktig det er å likestille f.eks. reineiernes tradisjonelle kunnskap med vestlig vitenskap.

Det er sammenfallende observasjoner fra befolkningen langs hele den arktiske regionen om endringer i klima, og disse kan oppsummeres som følger:

- Ustabilt vær, med endret værmønster og mindre forutsigbarhet

- Endret snøkvalitet

- Mer regn om vinteren

- Synkende vannivå i innsjøer

- Endret artsmangfold

- Dårligere tilgang på lav og mose, og følgelig redusert reinbestand

- Havisen krymper, istykkelsen endrer seg, tid for smelting og tilfrysning forandrer seg

- $\quad$ Store bølger medfører erosjon i kystområdene

- Sola føles sterkere og mer stikkende. Solbrenthet og nye typer hudutslett blir mer vanlig

- Klimaendringer skjer for raskt til at man rekker å tilpasse seg

- Introduksjon av snøscootere har redusert tilpasningsevnen da reindriften har blitt mer væravhengig. 
Økt skipstrafikk og ferdsel kan bli resultatet av redusert ismengde og bedre framkommelighet via Nordvestpassasjen og Nordøstpassasjen. Dette reiser spørsmål omkring suverenitet og sikkerhet, både når det gjelder skipsruter og naturressurser. En følge av bedre mulighet for transport og offshorevirksomhet vil være krav om nye og reviderte nasjonale og internasjonale reguleringer som har fokus på marin trygghet og beskyttelse av miljøet. Samtidig ser vi mulighet for konflikter mellom konkurrerende brukere av de arktiske vannveiene og kystområdene. Nordøstpassasjen og Nordvestpassasjen kan dermed bli framtidige konfliktområder der kommersielt fiske, seljakt, jakt på marine villdyr, turisme og shipping konkurrerer om å bruke de smale beltene med isfritt hav. De samme beltene vil også være de rutene marine pattedyr vil forflytte seg i.

\section{Tilpasning og sårbarhet}

Det er generell enighet om at endringer i klima og relaterte forhold vil gi utfordringer for samfunn, men hva endringene innebærer og hvordan de ulike samfunn takler dem, er det stor usikkerhet omkring. De ulike klimaog miljøforholdene som lokalsamfunn er følsomme overfor har ikke blitt dokumentert i særlig grad. Strategiene som er brukt for å takle endrede klima- og miljøforhold over hele Arktis er ikke blitt tilstrekkelig utredet. Forholdene som legger til rette for eller begrenser tilpasningskapasiteten og motstandsdyktigheten i lokale samfunn i nordområdene har ikke blitt underbygd. Lokal eller tradisjonell kunnskap har ennå ikke blitt integrert med vitenskaplig kunnskap i forsøk på å forstå hva slags muligheter som finnes for å bedre takle et klima i endring.

For å forstå disse forholdene og dekke disse kunnskapshullene er det derfor behov for å videreutvikle begrepet om tilpasning og sårbarhet og forbedre tverrfaglige forskningsmetoder. Det er videre nødvendig å identifisere sosiale og miljømessige påvirkningsfaktorer (multiple stressors), undersøke hvordan disse henger sammen og påvirker hverandre, og dokumentere prosesser som former tilpasningsevne og sårbarhet. I tillegg må vi forbedre forståelsen av sammenhengen mellom sårbarhet på lokalt nivå og beslutningsprosesser relatert til tilpasning. Dette er et forskningsområde hvor en felles nordisk innsats kan bidra til å dekke omfattende kunnskapshull omkring tilpasning og sårbarhet til klimarelaterte endringer. Sammenlignende studier av samfunn på tvers av landegrenser 
vil gi en større forståelse for de sosioøkonomiske prosesser og premisser som ligger til grunn for tilpasningskapasitet og sårbarhet.

\section{Ekstreme hendelser}

De nordiske landene er i utgangspunktet klimarobuste fordi de har store ressurser og mye nødvendig kunnskap for å kunne takle og tilpasse seg et endret klima (Norges Forskningsråd 2002). Likevel er det store geografiske variasjoner i Norden og tilpasningsutfordringer knyttet til klimaendringer varierer mellom de ulike regionene. For eksempel er Norge med sine bratte kyster, hvor store deler av landet er vant til dårlig vær, mindre sårbart for havnivåstigning enn danske kystområder. Men selv om de nordiske land på nasjonalt nivå sannsynligvis er mer robuste for klimaendringer enn de fleste andre land, og selv om evnen til å tilpasse seg er høy, så er ikke dette nødvendigvis tilfelle på lokalt og regionalt nivå (O’Brien m.fl. 2004). Det er for eksempel en rekke havner, byområder og andre lavereliggende kystnære deler av Norden som vil være sårbare for et høyere havnivå.

Det er forventet at ekstreme hendelser vil øke i hyppighet og omfang. Ekstreme værforhold i Norden vil som regel være nært knyttet til dannelse, bevegelse, utvikling og utstrekning av de såkalte ekstratropiske sykloner, dvs. lavtrykk. Disse dannes og utvikles over Nord-Atlanteren, og deres fremherskende bevegelse og utvikling i forhold til for eksempel Norges fjellkjeder og de vestvendte kystene blir avgjørende for fordeling av nedbør, vind og ekstremvær mellom landsdelene. I løpet av de siste 30-40 år har det vært en betydelig endring av lavtrykkenes systematiske oppførsel, noe som kan forklare mye av de «uvanlige» værtypene de siste 10-15 årene. Dessverre kan man ikke si med sikkerhet om dette skyldes klimagasser eller om det har vært en naturlig svingning som uansett ville ha kommet. Imidlertid kan man si at utviklingen på mange måter likner på noe av det som forutsies å komme som følge av menneskeskapte klimaendringer de neste 50-100 år (Førland m.fl. 2006). For å ha sammenligningsgrunnlag for projiserte klimaendringer 30-50 år frem i tid er det viktig å ha kunnskap også om observert variabilitet i hyppighet av naturulykker og klimaekstremer i løpet av de siste 50-100 år.

Ekstremvær i form av intens og langvarig nedbør og sterk vind, er spesielt knyttet til såkalte polare lavtrykk. Dette er en type sykloner som dannes og utvikles om vinteren over havområdene mellom fastlandet og 
havisen i Arktis. Disse syklonene er mye mindre i utstrekning enn vanlige lavtrykk (typisk en tidel eller mindre). De unnslipper derfor lett det relativt spredte observasjonsnettverket i Arktis, selv om de kan observeres på satellittbilder. Av denne årsak er ikke polare lavtrykks klimatologi godt bestemt og det finnes ingen klimamodeller som kan beregne dem med nevneverdig sikkerhet. Siden været som assosieres med polare lavtrykk kan være meget farlig, er dette en betydelig svakhet ved alle klimascenarier i vår region. Svakheten er spesielt viktig for nordområdene, inklusive de nordlige landsdelene (Førland 2006). Dette er et område hvor et styrket nordisk samarbeid kunne vært svært fruktbart.

De regionale klimanedskaleringene i de ulike nordiske landene har i stor grad fokusert på gradvise klimaendringer, der framskrivningene ikke har fanget opp sannsynligheten for ekstreme hendelser. Dette er et felt hvor nordisk samarbeid og utvikling av en felles metodologi for ekstreme værhendelser vil være av svært stor nytte. ${ }^{6}$

Samfunnsmessige konsekvenser av ekstreme hendelser er noe vi foreløpig vet lite om. Det er derfor behov for økt kunnskap når det gjelder lokalsamfunns kapasitet til å takle konsekvensene av ekstreme værhendelser som orkaner, jordskred, snøskred og flom. Disse værhendelsene skjer lokalt og responsen må derfor være lokal. Men samtidig er det behov for bedre forståelse for hvordan lokalsamfunnenes utvikling av strategier for klimatilpasning i tillegg må forankres i nasjonal politikk og budsjetter (bl.a. Næss m.fl. 2005; Næss m.fl. 2004; Kates og Wilbanks 2003; Smit og Pilisofova 2001).

Nordiske land ligger langt fremme både når det gjelder utvikling av regionale klimamodeller og statistisk nedskalering som verktøy for å kunne forutsi hvordan klimaet vil endre seg i fremtiden. I ACIA ga de svenske og norske regionale modellene SweClim og RegClim sammen med statistisk nedskaleringsteknikker de mest høyoppløselige og nøyaktige klimascenariene, og dermed de mest anvendbare resultatene for vurderingen av framtidige konsekvenser av klimaendringer i Arktis. Uten en videre utvikling av dette modellverktøyet vil det bli vanskelig å forbedre

\footnotetext{
${ }^{6}$ Danmarks Meteorologiske institut har gjort en del framskrivninger av ekstremvær for Europa, men ikke så langt nord som Arktis. SweClim (SWECLIM - Swedish Regional Climate Modelling Programme) og det norske RegClim-prosjektet (Regional Climate Development Under Global Warming) har i begrenset grad gjort gode framskrivninger av ekstremvær, men også Bjerknes Senter for klimaforskning skal i forbindelse med GeoExtreme-prosjektet starte med dette.
} 
presisjonsnivået i forutsigelsene av konsekvensene for natur og samfunn av klimaendringer i Arktis. Det anbefales at prosjektet spesielt ser nærmere på mulig samarbeid mellom nordiske forskningsmiljøer for å styrke arbeidet med klimascenariene.

Anbefalinger: Virkninger på samfunn, mennesker og institusjoner i Arktis

\subsubsection{Tilpasning og Sårbarhet}

- En hovedstudie bør vurdere nordisk samarbeid omkring sammenlignende studier av sårbarhet og tilpasning på ulike nivå innen og på tvers av samfunn

- Hovedstudien bør på et overordnet nivå kartlegge beslutningsprosesser om tilpasning, og tilpasningsstrategier til klimaendringer i de ulike land. Tilpasning skjer lokalt, men beslutningene skjer på ulike nivå (i de ulike landene).

\subsubsection{Ekstreme Hendelser}

- Hovedstudien bør også kartlegge kunnskapsbehov om lokal kapasitet og respons på ekstreme værhendelser, fordi ekstremhendelser er det som berører oss sterkest og først.

- Hovedstudien bør kartlegge omfanget av kunnskap/informasjon om hvordan klimaendringene vil påvirke hyppigheten og omfanget av ekstreme hendelser og vurdere verdiskapningen økt samarbeid vil gi for de nordiske land.

- De regionale klimanedskaleringene i de ulike nordiske land har i stor grad fokusert på gradvise klimaendringer og framskrivningene har ikke fanget opp sannsynligheten for ekstreme hendelser. Hovedstudien bør vurdere hvordan nordiske land best kan samarbeide og utvikle en felles metodologi for å varsle ekstremvær.

\subsection{Nedskalering av klimascenarier}

- Det anbefales at hovedstudien vurderer hvordan et nordisk samarbeid omkring videre utvikling av metode og utførelse av høyoppløselige statistisk og empirisk nedskalering av klimadata kan styrkes. 


\subsubsection{Klimaendringenes effekt på natur og miljø.}

En global oppvarming og et endret klima vil først og fremst innebære endrede fysiske forhold som økt temperatur, økt havnivå og økt nedbør i vår region. Disse endringene vil påvirke økosystem og samfunn både direkte og indirekte. ACIA-rapporten beskrev i detalj virkninger på natur og miljø (ACIA faktaark, CICERO 2005).

\section{Endringer i biologisk mangfold}

Globale klimaendringer har hatt mer dramatiske utslag i Arktis enn i verden for øvrig. Gjennomsnittstemperaturen har økt nesten dobbelt så mye som på lavere breddegrader de siste tiårene. ACIAs klimamodeller har ved hjelp av ulike utslippsscenarier forespeilet gjennomsnittlige temperaturøkninger i Arktis på om lag 4-7 grader celsius innen 2100. Klimaendringer vil sannsynligvis forandre livsgrunnlaget til arktiske dyrearter dramatisk, men det er stor usikkerhet om hvilke konsekvenser dette vil få. Redusert havis vil begrense leveområdene for mange dyrearter som isbjørn og enkelte selarter. Flere klimamodeller antyder at sommerisen kan bli redusert med 50 prosent eller forsvinne helt innen slutten av dette århundret.

Varmere vintre er forventet å føre til økt insektskade på skogene. Europeisk furusagflue har allerede gjort stor skade på skogen i den russiske delen av den arktiske regionen som Norge tilhører. Flere insekter og flere skogbranner kommer høyst sannsynlig som følge av varmere klima. Økt forekomst av skogbranner vil øke utslippene av $\mathrm{CO}_{2}$ og sotpartikler til atmosfæren.

Mange av de tilpasningene som gjør arktiske arter, eksempelvis reinsdyr og trekkfugler, i stand til å overleve, begrenser også deres evne til å konkurrere med arter som invaderer leveområdene deres på grunn av klimaendringene. Etter hvert som mer sydlige arter forflytter seg opptil 1000 kilometer nordover, vil disse svært sannsynlig overta områdene for arktiske arter med begrensede forflytningsmuligheter på grunn av havområdene i nord.

\section{Klimaendringenes virkninger på skog og vegetasjon}

De viktigste vegetasjonssonene i Arktis er den polare ørkenen, tundraen og den nordlige barskogen. I disse sonene er det forventet en økning av årsmiddeltemperaturen på om lag $3^{\circ} \mathrm{C}$ i Skandinavia og Øst-Grønland, 
om lag $2^{\circ} \mathrm{C}$ på Island og $6^{\circ} \mathrm{C}$ i de sentrale havområdene i Arktis. Gjennomsnittlig vintertemperaturer er forespeilet å øke med $3-5^{\circ} \mathrm{C}$ i de fleste landområdene og med opptil $6^{\circ} \mathrm{C}$ i Nordvest-Russland. Dette vil ha omfattende konsekvenser.

Mose og lav danner basis i viktige næringskjeder på Arktis, og er spesielt sårbare for oppvarming. Mindre mose og lav vil få store følger reinsdyrbestanden, og dermed indirekte påviske bestanden av polarrev, fugl, ulv, jerv. Dominoeffekter i næringskjeden kan bli en alvorlig følge av klimaendringer på arktisk skog og vegetasjon. Noen lokalsamfunn er spesielt avhengige av reindrift og vil følgelig være ekstra sårbare overfor endringer i mose og lavbestanden.

Vekstsesongen vil forlenges, og bar - og bjørkeskog vil antaes å bevege seg nordover. Skogområder i Arktis representerer om lag 31 prosent av verdens skog og spiller en viktig rolle i vannkretsløpet. Klimaendringer kan forandre viktige funksjoner knyttet til kretsløpet av vann. Som en følge av klimaendringer forventes det også at alpine områder blir redusert eller forsvinner helt.

Dersom nedbørsmengden ikke øker nok i forhold til fordampning er det også en risiko for Arktisk ørkendannelse.

\section{Klimaendringers virkninger på det marine miljø}

NordForsks forskningsprogram Vestnordisk Oceanklima 2000-2005 undersøkte havstrømmers virkning på fiskestammene. De nordiske land, særlig Grønland, Island, Færøyene og Norge, ligger i et havområde hvor samspillet mellom varme og kalde havstrømmer er avgjørende for klimaet og dermed for både levevilkår og fiskebestander (NordForsk 2005).

Den østlige delen av Nord-Atlanteren domineres av den varme Nordatlantiske Golfstrømmen som skaper et mildt klima 5-10 grader høyere enn det ellers ville ha vært. De vestlige områdene påvirkes derimot av den kalde Øst-grønlandske strøm og dens østlige utløp, den Øst-islandske strøm. Samspillet mellom disse tre hovedstrømmene er avgjørende for klimaet og forholdene for store deler av de vestlige deler av Norden. Samtidig inngår de i et system som driver dyphavssirkulasjonen i Verdenshavene og er dermed også viktige for hele det globale klimasystemet.

Den klimatiske avhengigheten av havstrømmene gjør det vestlige Norden svært avhengig av strømmenes veier og deres intensitet. I dette århundret er det observert flere eksempler på havklimatiske endringer 
som i stor grad har påvirket det marine økosystem og fiskeri. Fra historiske og paleo-oseanografiske undersøkelser har man tegn på mer dramatiske endringer, og klimamodeller forutsier at det som følge av antropogene utslipp av klimagasser kan forventes endringer i havstrømmene som også vil innebære svekkelse av Golfstrømmen.

Disse modellene er i dag for enkle til at prognosene kan gjøres sikrere og det er derfor et stort behov for forskning på området. Numerisk modellering er nødvendig for å få en kvantitativ beskrivelse av systemet og bedre prognoser.

Havfiske i Arktis er en viktig del av den globale mattilførselen og bidrar til økonomien i regionen. Klimaendringer vil påvirke områder som er sterkt avhengige av fiske. Noe varmere vann kan forvente å øke vekstraten hos fisk som torsk og sild, men en mer merkbar oppvarming kan overstige temperaturtoleransen hos ørret og laks. I tillegg vil varmere vann ha andre negative effekter, som økt forekomst av sykdommer og giftige alger. Det er en mulighet for at oppvarming vil føre til store forandringer i økosystemene og artsvariasjonen enkelte steder, men dette er vanskelig å forutsi.

Reker er en art som kan oppleve at leveområdet deres krymper som følge av oppvarming. Dermed kan den årlige grønlandske fangsten på om lag 100000 tonn reker bli kraftig redusert. Siden reker er viktig mat for torsk, kan en redusert rekebestand igjen føre til en dårligere matsituasjon for en voksende torskestamme. Sannsynligvis vil rekefisket måtte vike for sikringen av det mer innbringende torskefisket.

Klimaendringer går hånd i hånd med sosiale og økonomiske endringer. Lokale forhold og holdninger er avgjørende faktorer i forhold til klimapåvirkningene. Forvaltningsbeslutninger og avtaler om fangstkvoter kommer til å bli helt avgjørende for hvordan klimaendringer påvirker livet i havet og bestandenes størrelse og utbredelse.

Anbefalinger: Effekter på natur og miljø

Klimaendringene vil berøre en rekke miljøforhold i Arktis og Norden forøvrig, men hovedstudien bør i hovedsak fokusere på følgende områder:

- $\quad$ Kartlegge hvilke ulike marine og landbaserte økonomiske sektorer (fiskeri, landbruk, reindrift og skogbruk) som vil berøres mest av 
klima- og miljørelaterte endringer, og hvilke som er mest sårbare i forhold til samfunnenes muligheter for tilpasning til andre sektorer.

- Kartlegge hvilke klimarelaterte miljøendringer, herunder viktige naturressurser, som er mest relevante for folk og samfunn og kunnskapsbehovene for å forstå disse.

- Kartlegge områdene innen resursforvaltning og sikkerhetspolitikk som vil bli påvirket av klimaendringer og som vil ha konsekvenser for Norden som region.

- Kartlegge kunnskapsbehovet/kunnskapshull for klimaendringer og biologisk mangfold.

- Kartlegge hvordan klimaendringer påvirker opptak og utslipp av klimagasser fra arealer (f.eks. metanutslipp fra tundraen) og hvordan slike prosesser kan påvirke klimaet.

\subsubsection{Overvåking}

Det er i Arktis at klimaendringene kommer først og sterkest. Arktis er også en unik lokalisering for å foreta målinger av klimagasser. Derfor bør hovedstudien ha som siktemål å kartlegge overvåkingsbehov i disse områdene, og å etablere en felles nordisk plattform for overvåking. Hovedstudien bør videre vurdere hvordan et samarbeide konkret kan tilrettelegges, for eksempel gjennom et overvåkingsprogram eller etablering av et senter.

Temperaturøkning i nordområdene vil åpne opp for økt utnyttelse av både kjente og ukjente naturressurser, og dermed vil den menneskelige aktiviteten øke. Større aktivitet innen fiskeri, skipstrafikk, og olje- og gass virksomhet vil øke behovet for overvåking av de klimatiske forholdene. Åpning av nordøstpassasjen (og også nordvestpassasjen) ved reduksjon av havisens utbredelse vil få konsekvenser for oljevernberedskap og den sikkerhetspolitiske og militære overvåkingen i området.

I dag er det f.eks. kun èn værbøye i Barentshavet og behovet for bedre overvåking av klima- og værforholdene er nødvendig. Beregninger av fremtidige trender tyder helt klart på at det vil bli flere ekstreme værhendelser, og det er et klart behov for å videreutvikle forståelsen av forholdet mellom klimaendringer og slike hendelser. Arktis og nordområdene mangler i stor grad værobservasjoner som kan kobles mot klimaendringer. 
I tillegg til overvåking av vær, er is, temperatur, havstrømmer, nedbør og vind nødvendig å overvåke for å forstå ekstreme hendelser i Arktis, Barentshavet og nordområdene inklusive Baltikum.

\section{Anbefalinger: Overvåking}

- Vurdere hvilken rolle en nordisk koordinering av overvåking vil kunne ha i en større internasjonal sammenheng, og hvordan et nordisk overvåkingssamarbeid i Arktis kan knytte seg til eksisterende programmer i Europa og Nord-Amerika.

- Vurdere forutsetningene for å få samkjørte dataserier fra overvåking fra de ulike nordiske land.

- Kartlegge behovet for overvåking i nordområdene innen klimaendringers virkninger på miljø og biologisk mangfold, samt hvordan det innvirker på opphopningen av annen forurensing som tilføres Arktis.

- Vurdere hvorvidt det er hensiktsmessig å koordinere overvåking av klima og havsirkulasjon for å se disse endringsprosessene i sammenheng.

- Øke overvåking av is, temperatur, havstrømmer, nedbør og vind i Arktis, Barentshavet og nordområdene inklusive Baltikum for å øke forståelsen av ekstreme hendelser i nordområdene.

- Vurdere om det er grunnlag for et utvidet nordisk samarbeid omkring økt overvåkingen av flere klimagasser (her kan for eksempel værobservatoriet på Svalbard, Zeppelin-fjellet brukes).

- Hovedstudien bør vurdere et utvidet Nordisk samarbeid om karbonfluks-målinger (her er alle land med nå unntatt Norge og Russland).

- Hovedstudien bør vurdere muligheten av å overvåke smelting av permafrost og å knytte konsekvensene av dette til infrastruktur og samfunn.

\subsection{Geografiske avgrensninger}

I den Nordiske strategien for klima og miljøgifter er det geografiske området avgrenset til «de delene av Norden som ligger innenfor det arktiske området» slik dette er definert av Arktisk Råds arbeidsgruppe Arctic Mo- 
nitoring and Assessment Programme (AMAP) ${ }^{7}$ og i ACIA- rapportene (ACIA 2004; ACIA 2005). I ACIA ble det definert fire subregioner, hvorav subregion I dekket den nordligste del av Atlanterhavet med landområdene omkring. Denne subregionen omfatter alle de nordiske landene, men bare den østligste halvdel av Grønland.

De tradisjonelle arktiske områdene, som definert i AMAP og AHDR, dekker ikke hele det nordiske området. Når det gjelder klima er det imidlertid lite hensiktsmessig å holde seg kategorisk til disse geografiske grensene fordi klimaendringene i praksis vil berøre større områder. I ACIA prøvde man å følge AMAP-definisjon av Arktis, men i praksis ble mye større områder inkludert. En tilsvarende pragmatisk tilnærming bør en også bruke når det gjelder Norden. Det innebærer at det anbefales at de arktiske delene av Norden tillegges størst vekt i hovedstudien, mens det praktiske arbeidet vil inkludere de fem nordiske land og de selvstyrende områdene. Dessuten bør annen kunnskapsproduksjon fra Arktis av relevans for samfunnsplanlegging og forskning i de nordiske landene inkluderes.

\subsection{Samarbeidspartnere i hovedstudien}

Klimaendringer berører mange aspekter innen forskning og politikk, som for eksempel effekter av klimaendringer på samfunn, miljø og økosystemer, tilpasning og sårbarhet på den ene siden, og ulike mitigation-tiltak på den andre. Hovedstudiens oppgave blir å vurdere hvilke områder som er best egnet til nordisk koordinering og forskningssamarbeid. Ettersom hovedstudien er tenkt å være et viktig planleggingsverktøy for nordisk klimaforskning bør den gjennomføres i regi av ett institutt i samarbeid med Nordforsk og under hovedoppsyn av forskningsrådene i de nordiske landene. Dette kan for eksempel gjøres gjennom en styringskomité, eventuelt sammen med representanter for Nordisk Ministerråd dersom det er ønskelig.

\footnotetext{
${ }^{7}$ Miljøovervåkningsprogrammet Arctic Monitoring and Assessment Programme (AMAP) er en arbeidsgruppe under Arktisk Råd som gjennomfører og koordinerer arbeid relatert til kartlegging og overvåking av forurensning av planter, dyr og mennesker i Arktis. AMAP har gitt ut en rekke rapporter relatert til ulike problemstillinger knyttet til miljøgifter i Arktis. Sekretariatet ligger i Oslo.
} 
For den operasjonelle gjennomføring av hovedstudien vil det vært ideelt om alle de nordiske landene deltar med en representant hver, men dette er neppe gjennomførbart innenfor gitte budsjettrammer. Det foreslås at samarbeidspartnerne i hovedstudien deles i tre kategorier:

1. En koordinator (Nordforsk) som representerer de nordiske land/forskningsrådene, som sammen med ett faginstitutt har ansvaret for koordinering, innsamling av data, sammenstilling og overlevering av prosjektet.

2. Et lite utvalg partnere som har ansvaret og er rådgivende innenfor hvert av område i hovedstudien samt inkluderes i budsjettet (se budsjettforslag nedenfor).

3. Eksperter fra relevante institutter som vil bli kontaktet for oppdatert informasjon og som dermed får en rådgivende funksjon. Relevante institutter kan være meteorologiske institutter som arbeider med nedskaleringer og klimascenarier, havforsknings- og terrestriske institutter med kompetanse på overvåking og prosessforståelse, og tverrfaglige samfunnsvitenskapelige institutter.

\subsection{Budsjett, organisering og leveranser}

\subsubsection{Budsjett}

Vi presenterer her et enkelt budsjett uten kostnadsdetaljer, men som viser fordelingen innen gitte budsjettrammer. Kostnadsdetaljer som timesatser, reise og opphold til Workshop'en vil variere i forhold til hvem som utfører arbeidet og hvor Workshop'en holdes.

Se notater til budsjettet nedenfor.

$\begin{array}{ll}\text { Koordinator } & \text { timebasert arbeid } \\ \text { Faginstitutt } & \text { timebasert arbeid } \\ 4 \text { partnere } & \text { timebasert arbeid } \\ \text { Workshop } & \text { reise, opphold for }+20 \text { deltagere, andre kostnader } \\ \text { TOTALT } & \end{array}$

DKK 160.000

DKK 380.000

DKK 160.000

DKK 100.000

DKR 800.000 
Noter til budsjettet:

- Koordinator: Budsjettet tar utgangspunkt i at Koordinator har hovedansvaret for hovedstudien i forhold til i. framdrift, og ii. i forhold til at de forskningspolitiske aspektene (forskningsråd, forskningsstrategier) er ivaretatt

- Faginstitutt: har også et koordinerende ansvar på faglig nivå i forhold til at i) materialet som samles inn er det mest relevante og oppdaterte, ii) det faglige ansvaret for et av temaene som beskrevet i 3.1 ovenfor, og iii) hovedansvaret for å analysere innspillene og sammenstilling av studien. Gitt at hovedstudiens tyngdepunkt vil være den menneskelige dimensjonen bør faginstituttet ha ekspertise og kompetanse i å se ulike arktiske forhold og klimaendringer i forhold til folk og samfunn.

- Partnere: Det bør være maksimum fire partnere i tillegg til koordinator og faginstitutt som vil dekke en av de fem temaområdene (samfunn, terrestrisk miljø, marint miljø, overvåking og en for klimascenarier). Budsjettet er ikke tilstrekkelig til å dekke kostnadene ved å involvere flere partnere. En Workshop vil derfor være en viktig del av hovedstudien for å sikre faglig bredde og kompetanse.

- Workshop:_Det vil være nødvendig å arrangere en Workshop tidlig i prosessen for å samle fagmiljøene for å diskutere tilgjengelige og oppdaterte data. Det vil være nyttig at oppdragsgiverne er tilstede. For at en slik Workshop skal være effektiv og nyttig bør minst fire deltagere innenfor de ulike temaene inviteres, til sammen rundt 20 deltagere.

\subsubsection{Organisering}

Forskningsrådene i de nordiske land bør ha det overordnete ansvaret for hovedstudien, som sammen med en egen styringsgruppe vil ha det overordnede ansvaret for framdriften. En slik gruppe bør være sammensatt av representanter fra forskningsrådene og Nordisk Ministerråd. Faginstituttet vil ha ansvaret for å samle inn, og sammenstille materiale og ha kontakt med de ulike partnerne og sammen med koordinator ha kontakt med oppdragsgiver. Partnerne får en todelt rolle som rådgivere, for å sikre at 
det mest oppdaterte materialet blir inkludert i studien, og som leverandører av fagkunnskap.

Rapporten fra hovedstudien bør følge disposisjonen for et prosjektmandat og inneholde følgende elementer:

- Formål: Hvorfor gjøre denne hovedstudien?

- Mål: Hva skal studien oppnå, og hva og hvordan skal dette leveres?

(For eksempel en rapport, en fullstendig prosjektbeskrivelse for videre arbeid, eller utførlige anbefalinger).

- Scope/avgrensning, tematisk, faglig og geografisk.

- Interessenter/målgrupper

- Innhold

- Leveranser, fremdriftsplan

- Økonomi/budsjett

- Organisering

\subsubsection{Leveranser og framdriftsplan}

Framdriftsplan

$\begin{array}{ll}\text { 01.02.07 } & \text { Koordinatorer identifisert. Oppstart. } \\ \text { 15.02.07 } & \text { Etablere samarbeidspartnere } \\ 20.03 .07 & \text { Workshop } \\ 30.04 .07 & \text { Innlevering av materiale fra partnere } \\ 01.06 .07 & \text { Utkast til rapport } \\ 15.06 .07 & \text { Kommentarfrist } \\ 30.06 .07 & \text { Avlevering }\end{array}$

\subsection{Verdien av styrket nordisk forskningssamarbeid}

Hovedstudiens oppgave er å vurdere på hvilke områder det er potensial for bedre nordisk samarbeid, og i hvilken grad en slik koordinering styrker Norden som region internasjonalt. Norden har et unikt utgangspunkt i mulighetene av å koordinere og samarbeide omkring hvordan vi kan kartlegge mangler og svakheter i eksisterende kunnskap, hvordan vi kan rette på dette, og hvordan vi kan utnytte denne kunnskapen på best mulig måte 
både innenfor de enkelte Nordiske land, innenfor Norden som en enhet og internasjonalt. Slik kunnskap er nyttig og interessant i seg selv, men den har også verdi fordi den kan bidra til at de enkelte nordiske land internt blir bedre i stand til å takle konsekvensene av klimaendringer for samfunn og miljø, og fordi økt forståelse kan bidra til at Norden som en enhet kan påvirke internasjonale prosesser og utvikling av strategier. Hovedstudien må derfor generelt vurdere i hvilken grad og på hvilke områder Nordisk forskningssamarbeid er fruktbart.

En slik verdiskapning kan vurderes i forhold til:

1. Hvert enkelt nordisk land. Lærer vi noe om våre egne samfunn som vi ikke oppdager når vi bare tenker nasjonalt?

2. I hvilken grad og på hvilken måte vil denne type kunnskap og forståelse være relevant for det internasjonale samfunn?

3. Kan og bør Norden opptre med en mer «samlet front» internasjonalt?

4. Kan styrket nordisk forskningssamarbeid styrke og utvikle en felles nordisk forhandlingsposisjon om den «arktiske dimensjonen» i IPCC og i klimaforhandlingene under Kyotoprotokollen og Klimakonvensjonen? 


\section{Konklusjon}

Kapitlene ovenfor viser at temaet «klimaendringer i Arktis» er et stort og omfattende forskningsområde. I dette dokumentet har vi presentert en rekke anbefalinger for en hovedstudie av hvordan de nordiske land kan koordinere og samarbeide om forskning på klima- og klimarelaterte endringer.

Basert på kapittel 3 og anbefalingene til hovedstudien er det nærliggende å antyde noen hovedområder hvor det er størst potensial for et nordisk samarbeid som kan gjøre en forskjell i forhold til koordinering og samarbeid som foregår på andre nivåer og arenaer, som for eksempel i EU, Arktisk Råd og i de enkelte landene. På overordnet nivå bør hovedstudien kartlegge pågående forskning på klima, identifisere hvor det er mangler og svakheter i eksisterende forskning, og foreslå hvordan et nordisk samarbeid kan rette på dette og gjøre en forskjell i forhold til annet samarbeid.

Det understrekes at det bør være en premiss for hovedstudien at den skal fremme forslag på områder der nordisk samarbeid kan bidra med noe ekstra eller særskilt i forhold til andre samarbeidskonstellasjoner eller regionalt samarbeid.

Hovedstudien bør vurdere nærmere koordinerings- og kunnskapsbehov innen følgende hovedområder:

- Samfunn: Sammenlignende studier og bredere forståelse av samfunnenes tilpasningsstrategier, kapasitet og sårbarhet. Herunder forståelse av sammenhengen mellom ulike påvirkningsfaktorer multiple stressors (klima, miljø og samfunn)

- Klimascenarier: Videre utvikling av regionale klimamodeller, og statistisk og empirisk nedskalering. 
- Overvåking: Utvikling av plattformer for overvåking av miljø og klima

- Prosessforståelse: Øke forståelsen av hva som påvirker klimautviklingen i Nordområdene både terrestrisk og marint.

I mer detalj anbefales følgende:

Samfunn: Tilpasning og sårbarhet

Hovedstudien bør:

- Vurdere nordisk samarbeid omkring studier av sårbarhet og tilpasning på ulike nivå i samfunnet

- Kartlegge kunnskapshull og behov om hvordan klimaendringene vil påvirke hyppigheten og omfanget av ekstreme hendelser, og vurdere verdiskapningen økt samarbeid vil gi for de nordiske land.

- Kartlegge beslutningsprosesser om tilpasning, og tilpasningsstrategier til klimaendringer i de ulike land. Tilpasning skjer lokalt, men beslutningene skjer på ulike nivå (innenfor og mellom de ulike landene).

- Kartlegge behov for kunnskap om lokal kapasitet og respons på ekstreme værhendelser. Ekstremhendelser er det som berører oss sterkest og først.

- Kartlegge områdene innen resursforvaltning og sikkerhetspolitikk som vil bli påvirket av klimaendringer og som vil ha konsekvenser for Norden som region.

\section{Klimascenarier}

- Styrke utviklingen av klimascenarier for de nordiske landene slik at både oppløsningen kan bedres og usikkerheten reduseres. De regionale nedskaleringene av klimascenariene i de ulike nordiske land har i stor grad fokusert på gradvise klimaendringer.

Framskrivningene har ikke i tilstrekkelig grad fanget opp sannsynligheten for ekstreme hendelser eller raske endringer. Dette er et felt hvor nordisk samarbeid og utvikling av en felles metodologi vil være av svært stor nytte.

- Nordisk samarbeid på videre utvikling av metode og utførelse av høyoppløselige statistisk og empirisk nedskalering av klimadata. 


\section{Overvåking}

Hovedstudien bør:

- Vurdere hvilken rolle en sterkere nordisk koordinering av overvåking vil kunne ha i en større internasjonal sammenheng.

- Vurdere hvordan et nordisk overvåkingssamarbeid i Arktis kan knytte seg til eksisterende programmer i Europa og Nord-Amerika.

- Vurdere forutsetningene for å få samkjørte dataserier fra overvåking fra de ulike nordiske land.

- Kartlegge behovet for overvåking i nordområdene innen klimaendringers virkninger på miljø og biologisk mangfold.

- Øke forståelsen av ekstreme hendelser i nordområdene gjennom overvåking av is, temperatur, havstrømmer, nedbør og vind i Arktis, Barentshavet og nordområdene inklusive Baltikum

- Vurdere om det er grunnlag for økt nordisk samarbeid om å øke overvåkingen av flere klimagasser (for eksempel målestasjonene på Svalbard, Zeppelin-fjellet.)

\section{Prosessforståelse: Terrestriske og marine miljø}

Klimaendringene vil berøre en rekke miljøforhold i Arktis og Norden forøvrig, men hovedstudien bør i hovedsak fokusere på følgende områder:

- Kartlegge hvilke klimarelaterte miljøendringer, herunder viktige naturressurser, som er mest relevante for folk og samfunn og kunnskapsbehovene for å forstå disse.

- Dette området berører ulike marine og landbaserte økonomiske sektorer, som fiskeri, landbruk, reindrift og skogbruk. En hovedstudie bør kartlegge hvilke sektorer som vil berøres mest av klima- og miljørelaterte endringer, og hvilke som er mest sårbare i forhold til samfunnenes muligheter for tilpasning til andre sektorer.

- Kartlegge kunnskapsbehovet/kunnskapshull for klimaendringer og biologisk mangfold.

- Karbonsyklus med vekt på utslipp og opptak (økt utbredelse av det boreale skogbeltet) fra permafrost områder, i særlig grad fra 
tundraen, og på opptak i havet. Hvordan tilbakekoblinger fra endringene i karbonsyklus i Arktis kan påvirke det globale klimaet.

Denne forstudien har spent et bredt lerret og forsøkt å fange opp de mest nyttige områdene for videre studier av koordineringsbehov og forskningssamarbeid mellom de Nordiske land. Hovedstudien vil videre vurdere hvilke av disse som er mest relevante, gjennomførbare og som gir mest verdiskapning for de Nordiske land som region. Med ACIAs suksess friskt i minne, gitt et høyt ambisjonsnivå, og nordisk ledelse av Arktisk Råd de neste 6 år, kunne en nordisk ACIA være løsningen. 


\section{Summary}

The background to this preliminary study is the acceleration of climate change, especially in Arctic areas, and its consequences for the Nordic countries. The Center for International Climate and Environmental Research - Oslo (CICERO) has reviewed the different scientific issues that are relevant to studies of climate and environmental change. The purpose of the preliminary study is to design a main study that will analyse the need for knowledge and co-ordination in Nordic climate and environmental research, and also to map out the preconditions for long-term Nordic prioritisation of research into climate and environmental changes and their impact upon Arctic societies. Major importance has been attributed to the social aspects, as there is a great need to understand the direct and indirect consequences of climate change for the various populations and their resources and conditions.

There are a number of areas in which joint Nordic co-ordination and research co-operation will increase overall understanding, and in doing so will also improve economic growth in the Nordic countries. The preliminary study concludes that a main study should assess in greater depth the need for co-ordination and knowledge in four main areas:

- Society: Comparative studies and deeper understanding of societies' adaptation strategies, capacity and vulnerability, including an understanding of the links between different influencing factors multiple stressors (climate, environment and society).

- Climate scenarios: Further development of regional climate models, and statistical and empirical downscaling.

- Monitoring: Development of platforms for monitoring the environment and climate. 
- Process understanding: Increased understanding of the factors that impact upon the climate in the North, both on land and at sea.

The main study must assess economic growth in relation to whether coordination and research co-operation will improve the ability of the individual Nordic countries to tackle the social and environmental consequences of climate change, and whether the Nordic Region as a whole is able to influence international processes and strategy development. At the overall level, work like this should be headed up by the research councils in the different countries, in close co-operation with scientific experts. 


\section{Referanser}

ACIA (2005). Arctic Climate Impact Assessment. Cambridge University Press.

ACIA (2004). Impacts of a Warming Arctic. Summary report of the Arctic Climate Impact Assessment, Cambridge University Press, Cambridge, UK.

AHDR. (2004). Arctic Human Development Report. Stefansson Arctic Institute, Akureyri, Iceland. Cambridge University Press, Cambridge.

CICERO (2005). CICERO faktaark fra ACIA-utredningen, 12. januar 2005, http://acia.cicero.uio.no/faktaark/

Førland, Eirik m.fl. (2006) Upublisert notat. 02.10.06.

Huntington, H. and Fox, S. (2005). The changing Arctic: Indigenous perspectives. In: The Arctic Climate Impact Assessment Scientific Report. Kapittel 3 i Symon, C. (red.), Arctic Climate Impact Assessment. Cambridge: Cambridge University Press, 61-98.

ICARP. (2005). A research plan for the study of rapid change, resilience and vulnerability in social-ecological systems of the Arctic. Report from working group 10 of the Second International Conference on Arctic Research Planning IPY (2005).

IPY. (2005). International Polar Year Themes. http://www.ipy.org/ development/themes.htm Accessed 3rd September 2005.
Kates og Wilbanks (2003). «Making the Global Local: Responding to Climate Change Concerns from the Bottom Up», Environment, 45/3 (April 2003): 12-23

McCarthy et al. (2001). Climate Change 2001: Impacts, Adaptation, and Vulnerability. Cambridge University Press, Cambridge. Summary for Policymakers, 3-17.

McBean, G., Alekseev, G. V., Chen, D., Forland, E., Fyfe, J., Groisman, P. Y., King, R., Melling, H., Vose, R. and Whitfield, P. H. (2005). Chapter 2 in Symon, C. (ed.), Arctic Climate Impact Assessment. Cambridge: Cambridge University Press, 22-60.

Nordic Arctic Research Programme (2005). NARP Highlights - Contributions of the Nordic Arctic Research Programme http://thule.oulu.fi/narp/ assets/pdfs/NARPsummary.pdf

Norges forskningsråd (2002). Rikets miljøtilstand 2030 - et fremtidsbilde. Norges Forskningsråd.

Norges forksningsråd (2006) Handlingsplanen for klimaforskning. Norges Forskningsråd, 18. august 2006.

NMR (2006). Nordisk strategi for klima og miljøgifter i Arktis. Vedtatt på det nordiske miljøministermøtet i København 16. mars.

NordForsk (2005). Vestnordisk Oceanklima, http://www.nordforsk.org /meny.cfm?m=149,258 
Næss, Lars Otto, Guri Bang, Siri Eriksen and Jonas Vevatne (2005). Institutional adaptation to climate change: flood responses at the municipal level in Norway. Global Environmental Change, 15 (2): 125-138.

Næss, Lars Otto, Pål Prestrud, Karen O'Brien and Knut H. Alfsen (2004). Forstudie til klimatilpasningsstrategi for Norge. Report 2004:11. CICERO, Oslo. Norway. 45 pp.

O'Brien, Karen, Linda Sygna and Jan Erik Haugen (2004). «Vulnerable or resilient? Multi-scale assessments of the impacts of climate change in Norway», Climatic Change 64 (1-2): 193-225.

Smit, B., and O. Pilifosova (2001). Adaptation to climate change in the context of sustainable development and equity. Chapter 18 in IPCC Climate Change 2001: Impacts, Adaptation, and Vulnerability - Contribution of Working Group II to the Third Assessment Report of the Intergovernmental Panel on Climate Change. Cambridge, UK: Cambridge University Press.

Stran, Kari ved Thule Inst. Personlig kommentar 31.august 2006.

Utdannings- og forskningsdepartementet (2005). Vilje til forskning, St.meld. nr. 20 (2004-2005) 18. mars 2005.

Vitboken NORIA (2004). «Vitbok om nordisk forskning och innovation Huvudrapport». Nordisk Ministerråd, Temanord 2004: 502 


\section{Liste over forkortelser}

$\begin{array}{ll}\text { ACIA } & \text { Arctic Climate Impact Assessment } \\ \text { AMAP } & \text { Arctic Monitoring and Assessment Programme } \\ \text { AHDR } & \text { Arctic Human Development Report } \\ \text { BACCI } & \text { Biosphere-aerosol-cloud-climate interactions } \\ \text { ERA-nett } & \text { European Research Area } \\ \text { IASC } & \text { International Arctic Science Committee } \\ \text { ICARPII } & \text { International Conference on Arctic Research Planning } \\ \text { IPY } & \text { International Polar Year 2007-2008 } \\ \text { NARP } & \text { Nordic Arctic Research Programme } \\ \text { NECC } & \text { Nordic centre for studies of ecosystem carbon exchange and its interactions } \\ \text { NCoE } & \text { with the climate system } \\ \text { NFR } & \text { Nordic Centre of Excellence } \\ \text { NMR } & \text { Norges forskningsråd } \\ \text { NORIA } & \text { Nordisk ministerråd } \\ \text { RegCLIM } & \text { Nordic Research and Innovation Area } \\ \text { SWECLIM } & \text { Regional Climate Development Under Global Warming } \\ \text { UFA } & \text { Swedish Regional Climate Modelling Programme } \\ & \text { Avdelningen for utdanning, forskning og arbeidsliv }\end{array}$

